\title{
Penerapan Model Visualization Auditory Kinesthetic (Vak) Dengan Media Flip Chart untuk Meningkatkan Keterampilan Menulis Karangan Peserta Didik Kelas III SDN 2 Kebulusan Tahun Ajaran 2017/2018
}

\author{
Isnaeni Subekti ${ }^{1}$, Suhartono ${ }^{2}$, Imam Suyanto ${ }^{3}$ \\ 1,2,3 Universitas Sebelas Maret \\ subektiisnaeni@gmail.com
}

\section{Article History}

accepted 01/02/2019

\begin{abstract}
The objective of this research is toimprove story-writing skill for students. This research is a collaborative Classroom Action Research (CAR) which conducted in three cycles consisted of planning, action, observation and reflection. The result of this research showed thatthe application of VAK model using flip chart media can improve story-writing skill of students. It was proven by the increase of learning outcomes in the first cycle $75.86 \%$, in the second cycle $86.21 \%$, and in the third cycle $100 \%$. The conclusion of this research is the application of VAK model using flip chart media can improve story-writing skill for the third-grade students of SDN 2 Kebulusan in the academic year of 2016/2017.
\end{abstract}

Keywords: VAK, flip chart, story-writing skill

\begin{abstract}
Abstrak
Tujuan penelitian ini adalah meningkatkan keterampilan menulis karangan peserta didik. Penelitian ini adalah Penelitian Tindakan Kelas (PTK) kolaboratif yang dilaksanakan dalam tiga siklus terdiri dari perencanaan, pelaksanaan, observasi, refleksi. Hasil penelitian menunjukkan penerapan model VAK dengan media flip chart dapat meningkatkan keterampilan menulis karangan. Persentase ketuntasan siswa pada siklus I sebanyak $75.86 \%$, siklus II $86.21 \%$ dan siklus III $100 \%$. Simpulan penelitian ini adalah penerapan model VAK dengan media flip chart dapat meningkatkan keterampilan menulis karangan peserta didik kelas III SDN 2 Kebulusan tahun ajaran 2017/2018. Kata kunci: $V A K$, flip chart, keterampilan menulis karangan
\end{abstract}




\section{PENDAHULUAN}

Pendidikan bertujuan agar peserta didik dapat meningkatkan ketaqwaan terhadap Tuhan Yang Maha Esa, memperkuat kepribadian peserta didik, mempertinggi budi pekerti, mempertebal semangat cinta tanah air dan juga meningkatkan kecerdasan dan keterampilan. Keterampilan yang diperoleh peserta didik melalui pendidikan salah satunya adalah keterampilan berbahasa. Menurut Yunus, dkk. (2013: 1.19-1.20) sebagai salah satu komponen dalam keterampilan berbahasa, menulis merupakan kegiatan yang kompleks. Hal ini karena kegiatan menulis menuntut kemampuan penulis untuk dapat menata dan mengorganisasikan ide atau pemikiran secara runtut dan logis dan menyajikannya dalam ragam bahasa tulis dengan menggunakan kaidah penulisan.

Seseorang dikatakan terampil menulis bila yang bersangkutan dapat memilih bentuk-bentuk bahasa tertulis (berupa kata, kalimat, paragraf) serta menggunakan retorika (organisasi tulisan) yang tepat untuk dapat mengutarakan pikiran, perasaan, gagasan dan fakta. (Mulyati, dkk., 2009: 1.5).

Berdasarkan uraian tersebut maka seyogyanya setiap guru harus mampu memilih model maupun media pembelajaran yang menarik dan relevan agar dapat membuat peserta didik antusias dan terlibat secara aktif dalam proses pembelajaran sehingga mampu meningkatkan keterampilan berbahasa, khususnya keterampilan menulis.

Berdasarkan hasil observasi dan wawancara di SDN 2 Kebulusan pada tanggal 4 November 2017, dalam menyampaikan materi tentang manulis, guru masih belum menggunakan model atau media yang bervariasi. Guru masih lebih banyak menggunakan model ceramah dalam menyampaikan tentang materi menulis puisi media yang digunakan hanya sebatas contoh teks puisi. Hal ini menyebabkan kurang antusiasnya peserta didik dalam mengikuti pembelajaran yang sedang berlangsung. Selain itu, peserta didik cenderung masih pasif karena pembelajaran masih berpusat pada guru. Kondisi tersebut menghambat perkembangan keterampilan berbahasa peserta didik khususnya keterampilan menulis.

Sesuai dengan data hasil ujian tengah semester (UTS) semester ganjil peserta didik kelas III SDN 2 Kebulusan pada mata pelajaran Bahasa Indonesia diperoleh informasi bahwa masih banyak peserta didik yang belum memenuhi nilai KKM yang ditentukan. Dari keseluruhan peserta didik kelas III SDN 2 Kebulusan yang berjumlah 29 orang terdapat 13 peserta didik yang telah memenuhi nilai minimal KKM. Sedangkan 16 peserta didik lainnya masih belum memenuhi nilai minimal KKM yang ditentukan. Berdasarkan data tersebut maka diketahui bahwa masih ada 55,2\% dari seluruh peserta didik kelas III SDN 2 Kebulusan yang belum mampu menguasai materi Bahasa Indonesia dengan baik.

Menurut Taufiq, Mikasa dan Priyanto (2014: 2.6) dan Sagala (2013: 27) peserta didik kelas III SD berada pada rentang usia 9-10 tahun yang termasuk pada tahap operasional konkret. Anak dapat mengembangkan diri karena kemampuannya mulai meningkat, mereka dapat berpikir secara konseptual, memecahkan masalah, mengingat dan menggunakan bahasa dengan baik (Sumantri, 2013: 2.8). Kemampuan berbahasa anak pada tahap ini juga meningkat, anak mampu menggunakan bahasa yang halus dan kompleks (Anitah, dkk., 2011: 2.20-2.22).

Keterampilan menulis karangan peserta didik merupakan kecakapan menuangkan pemikiran yang dilakukan melalui 3 tahap (tahap prapenulisan, tahap menulis, dan tahap pascapenulisan) yang dilakukan secara terus menerus hingga membentuk tulisan yang menceritakan suatu peristiwa atau rangkaian peristiwa.

Mulyati, dkk. (2009:1.6) mengungkapkan bahwa seseorang dikatakan terampil menulis apabila yang bersangkutan dapat memilih bentuk-bentuk bahasa tertulis (kata, kalimat, paragraf) serta menggunakan retorika (organisasi tulisan) yang tepat guna mengutarakan pikiran, perasaan, gagasan dan fakta. Keterampilan menulis peserta didik dapat dinilai dengan memperhatikan kriteria berikut ini: 1) tema; 2) ketepatan isi 
dalam paragraf; 3) kesesuaian isi dengan judul; 4) ketepatan susunan kalimat; dan 5) ketepatan penggunaan ejaan.

Model VAK merupakan model pembelajaran yang mengoptimalkan tiga modalitas belajar (visual, auditory, kinesthetic) untuk menjadikan peserta didik merasa nyaman (Shoimin, 2014: 226).

Media flip chart merupakan papan tulis yang ditempeli dengan lembaranlembaran kertas yang disatukan dengan penjepit diujung atas papan (Marisa, dkk., 2014: 3.9). Media flip chart bertujuan untuk menunjukkan keterkaitan suatu objek (Daryanto, 2013: 119).

Langkah penerapan model pembelajaran VAK dengan media flip chart sesuai pendapat Shoimin (2014: 227-228) ada 4 yaitu: (1) tahap persiapan, (2) tahap penyampaian dengan menggunakan media, (3) tahap pelatihan dan (4) tahap penampilan hasil.

Penerapan model VAK dengan media flip chart diharapkan dapat memberikan kesempatan kepada peserta didik untuk belajar secara langsung menggunakan modalitas yang dimilikinya dan membantu menemukan ide/gagasan sebagai bahan menulis karangan sehingga dapat meningkatkan pemahaman mereka dan membuat pembelajaran yang lebih bermakna.

Berdasarkan uraian tersebut, rumusan masalah yang muncul yaitu: (1) bagaimanakah langkah-langkah penerapan model VAK dengan media flip chart, dan (2) apakah penerapan model VAK dengan media flip chart dapat meningkatkan keterampilan menulis karangan peserta didik kelas III SDN 2 Kebulusan tahun ajaran 2017/2018.

Penelitian ini bertujuan untuk: (1) mendeskripsikan langkah-langkah penerapan model VAK dengan media flip chart dalam peningkatan keterampilan menulis karangan, dan (2) meningkatkan keterampilan menulis karangan peserta didik kelas III SDN 2 Kebulusan tahun ajaran 2017/2018.

\section{METODE}

Pelaksanaan penelitian direncanakan akan dilaksanakan di SDN 2 Kebulusan pada pertengahan Tahun Ajaran 2017/2018, yaitu bulan November 2017 sampai bulan April 2018, dengan subjek penelitian adalah peserta didik kelas III SDN 2 Kebulusan tahun ajaran 2017/2018. Jumlah peserta didik kelas III adalah 29 peserta didik yang terdiri dari 18 peserta didik laki-laki dan 11 peserta didik perempuan.

Teknik pengumpulan data yang digunakan yaitu teknik tes (tes hasil belajar) dan non tes (observasi dan wawancara). Data yang diperoleh berupa data kuantitaif (nilai hasil belajar siswa) dan data kualitatif (informasi proses belajar).

Validitas data penelitian diuji menggunakan teknik triangulasi teknik dan sumber. Sugiyono (2009: 330) menyampaikan bahwa triangulasi merupakan teknik pengumpulan data dengan menggabungkan berbagai teknik pengumpulan data dan sumber data yang telah ada. Triangulasi sumber dalam penelitian ini yaitu observer, guru kelas III, peserta didik serta dokumen dan triangulasi teknik dengan teknik tes, observasi, wawancara dan dokumentasi.

Analisis data menggunakan model Miles dan Hiberman yang meliputi reduksi data, penyajian data, dan penarikan kesimpulan (Sugiyono, 2009: 334).

Indikator kinerja penelitian yang diharapkan adalah $80 \%$ yang meliputi aspek: (1) penerapan langkah model VAK dengan media flip chart untuk meningkatkan keterampilan menulis karangan; (2) respon peserta didik terhadap proses pembelajaran penyelesaian soal cerita melalui penerapan model CIRC dengan media ular tangga; (3) hasil keterampilan menulis karangan melalui penerapan model VAK dengan media flip chart dengan $\mathrm{KKM}=70$.

Prosedur penelitian merupakan siklus kegiatan yang dalam penelitian ini dilakukan selama tiga siklus dengan enam kali pertemuan. Masing-masing siklus meliputi 
perencanaan, pelaksanaan, observasi dan refleksi. Hal tersebut sesuai dengan pendapat Arikunto (2013: 16) yang menjelaskan bahwa penelitian tindakan kelas terdiri dari empat tahap yaitu perencanaan, pelaksanaan, observasi, dan refleksi

\section{HASIL DAN PEMBAHASAN}

Berdasarkan pelaksanaan tindakan selama tiga siklus yang dilaksanakan sebanyak enam kali pertemuan, secara keseluruhan pembelajaran dengan menerapkan model VAK dengan media flip chart untuk meningkatkan keterampilan menulis karangan peserta didik dinyatakan telah berhasil dengan sangat baik. Keberhasilan tersebut terjadi karena adanya peningkatan penerapan langkah-langkah model VAK dengan media flip chart dan hasil keterampilan menulis karangan pada setiap siklus sehingga persentase ketuntasan belajar siswa mencapai indikator kinerja penelitian yang diharapkan. KKM yang digunakan dalam penelitian ini yaitu 70 dan indikator pencapaian penelitian sebesar $80 \%$. Peningkatan langkah penerapan model VAK dengan media flip chart dapat dilihat pada tabel 1 .

Tabel 1. Hasil Observasi Penerapan Model VAK dengan Media flip chart terhadap Guru dan Peserta Didik pada Siklus I- III

\begin{tabular}{|c|c|c|c|}
\hline \multirow[t]{2}{*}{$\overline{\mathrm{No}}$} & \multirow[t]{2}{*}{ Siklus } & Persentas & Persentas \\
\hline & & $\begin{array}{l}\text { e bagi } \\
\text { guru }\end{array}$ & $\begin{array}{l}\text { e bagi } \\
\text { siswa }\end{array}$ \\
\hline 1. & I & $64.27 \%$ & $60.38 \%$ \\
\hline 2. & II & $79.24 \%$ & $79.55 \%$ \\
\hline 3. & III & $86.04 \%$ & $86.35 \%$ \\
\hline
\end{tabular}

Berdasarkan tabel 1, persentase hasil observasi guru dalam penerapan model VAK dengan media flip chart mengalami peningkatan di setiap siklusnya. Pada siklus I baru mencapai $64.27 \%$, pada siklus II sudah mencapai $79.24 \%$, dan pada siklus III mencapai $86.04 \%$. Persentase hasil observasi peserta didik dalam pelaksanaan pembelajaran juga mengalami peningkatan setiap siklusnya. Pada siklus I baru mencapai $60.38 \%$, pada siklus II mencapai $79.55 \%$, dan pada siklus III mencapai $86.35 \%$. Peningkatan tersebut sudah mencapai indikator kinerja yang diharapkan yaitu $\geq 80 \%$.

Keberhasilan penerapan model VAK dengan media flip chart juga sudah terbukti dari penelitian yang dilakukan Pratama, dkk. (2016: 1), bahwa persentase siklus I sebesar $68.94 \%$ meningkat menjadi $76.25 \%$ pada siklus II. Penelitian lain yang menguatkan adalah penelitian yang dilakukan oleh Wati,dkk. (2015: 1), bahwa persentase siklus I sebesar $62.5 \%$, siklus II 70.83 dan meningkat pada siklus III menjadi $87.5 \%$.

Perbandingan peningkatan hasil keterampilan menulis karangan siklus I, II dan III dapat dilihat pada tabel 2 .

Tabel 2. Peningkatan Hasil Keterampilan Menulis Karangan

\begin{tabular}{llll}
\hline & Siklus & Siklus & $\begin{array}{l}\text { Siklus } \\
\text { I }\end{array}$ \\
II & III \\
\hline Rata-rata & 70.79 & 76.59 & 84.45 \\
Persentase & 75.86 & 86.21 & 100 \\
Tuntas(\%) & & & \\
\hline
\end{tabular}

Berdasarkan tabel tersebut rata-rata nilai pada akhir siklus I adalah 70.79 atau $75.86 \%$, siklus II 76.59 atau $86.21 \%$ dan siklus III 84.45 atau $100 \%$. Dengan demikian 
penerapan model $V A K$ dengan media flip chart dapat meningkatkan keterampilan menulis karangan peserta didik.

\section{SIMPULAN}

Berdasarkan hasil analisis pelaksanaan penelitian, hasil peneli-tian dan pembahasan, maka dapat disimpulkan bahwa penerapan model VAK dengan media flip chart untuk meningkatkn keterampilan menulis karangan dilaksanakan sesuai langkahlangkah pembelajaran yaitu: (a) persiapan meliputi kegiatan pembangkit minat serta penyiapan materi dan media flip chart, (b) penyampaian dengan menggunakan media meliputi pembagian kerangka rumpang, penyajian media, pencarian informasi berdasarkan media flip chart penjelasan materi dan pembimbingan penentuan tema dan judul karangan, (c) pelatihan meliputi kegiatan penentuan tema dan judul karangan serta kegiatan pembimbingan penyusunan kerangka karangan menjadi karangan utuh, (d) penampilan hasil, meliputi kegiatan penampilan hasil karangan secara lisan dan tertulis serta kegiatan evaluasi menulis karangan. Penerapan model VAK dengan media flip chart dapat meningkatkan keterampilan menulis karangan peserta didik kelas III SDN 2 Kebulusan tahun ajaran 2017/2018.

Berdasarkan dari hasil pene-litian yang telah dicapai, peneliti memberikan saran kepada peserta didik seyogyanya memperhatikan penjelasan guru saat pembelajaran berlangsung, lebih aktif bertanya dan menjawab pertanyaan guru, serta melaksanakan tugas yang diberikan guru dengan penuh rasa tanggungjawab dan disiplin. Guru sebaiknya memperhatikan langkah-langkah penerapan model VAK dengan media flip chart agar proses pembelajaran berjalan sesuai dengan skenario pembelajaran agar dapat membuat peserta didik terlibat secara aktif dalam pembelajaran.

\section{DAFTAR PUSTAKA}

Anitah, S., dkk. (2011). Strategi Pemblajaran di SD. Jakarta: Universitas Terbuka.

Arikunto, S. (2013). Prosedur Penelitian. Jakarta: Rineka Cipta.

Daryanto. (2013). Media Pembelajaran Perannya Sangat Penting dalam Mencapai Tujuan Pembelajaran. Yogyakarta: Gava Media.

Marisa, dkk. (2014). Komputer dan Media Pembelajaran. Tangerang Selatan: Universitas Terbuka.

Mulyati, dkk. (2009). Keterampilan Berbahasa Indonesia SD. Jakarta: Universitas Terbuka.

Pratama,dkk. (2016). Penerapan Model Visualization, Auditory, Kinesthetic (VAK) untuk Meningkatkan Keterampilan Menulis Narasi. Jurnal Didaktika Dwija Indri, 4 (9) (1-8).

Sagala, S. (2013).Konsep dan Makna Pembelajaran. Bandung: Alfabeta.

Shoimin, A. (2014). 68 Model Pembelajaran Inovatif dalam Kurikulum 2013. Yogyakarta: Ar Ruzz Media.

Sugiyono. (2009). Metode Penelitian Pendidikan Pendekatan Kuantitatif, Kuaitatif, dan $R \& D$. Bandung: Alfabeta.

Sumantri, M. (2013). Perkembangan Peserta didik. Tangerang Selatan: Unversitas Terbuka.

Sumantri, M. (2013). Perkembangan Peserta didik. Tangerang Selatan: Unversitas Terbuka.

Taufiq, Mikasa, dan Priyanto. (2014). Pendidikan Anak di SD. Tangerang Selatan Universitas Terbuka.

Wati,D.H.,dkk. (2015). Peningkatan Keterampilan Menulis Narasi dengan Media Flip Chart. Jurnal Didaktika Dwija Indria, 3 (7) (1-6).

Yunus, dkk. (2013). Keterampilan Menulis. Tangerang Selatan: Universitas Terbuka. 